\title{
The Development of Weed Managerial Technique Using New Type of Weed Controllable Materials
}

\author{
Park, N. I. ${ }^{1 *}$, I. Y. Lee', J. E. Park' ${ }^{1}$, O. Kwon', S. H. Ji ${ }^{1}$ and S. H. Chae ${ }^{2}$ \\ ${ }^{1}$ NIAST, ${ }^{2}$ Chungnam Agriculture Techno-Park
}

\section{Objective}

At present, approaches to the biological control of weeds are broadly discussed. Thus, concern of consumers rise on the well-being conscious and organic cultivated agricultural products, and the development of new type weed controllable materials is demanded for weed control in arable land without the use of herbicide. The vinyl mulching among weed control methods wasn't recyclable material and the used vinyl removal result in heavy cost and labour. It also causes harmful discharges to environment when the used vinyl was incinerated. However, the various types of integrative approaches to biological control of weeds in crops have been studied such as the duck, a pond snail, rice bran, and other insect using cropping in the paddy fields. In this study, we examined the methods of weed control in the upland implementing by new type of weed controllable materials, which may maximize the impact of efficient weed control.

\section{Materials and Methods}

On 19 July 2004 , the test plot was set up $\left(2.0 \mathrm{~m}^{2}\right.$ plotting) at the national institute of agricultural science and technology (NIAST) field in Korea, after weed seedlings were removed with glufosinate ammounium on the plowing upland. The dosage of new type of weed controllable materials in this experiment were presented at table 1 . Following the treatment, hot pepper and cabbage were transplanted for crop injury with dose of new type weed controllable materials. To find the relationship of weed suppression and soil surface hardness, Soil surface hardness was investigated by soil hardness meter on 9 days after application (DAA). The weed suppression value was calculated on 58 DAA.

\section{Results and Discussion}

Soil surface hardness was shown at the table 2. Soil surface hardness of WMD-01 and WMD-02 plots showed 1.3 and 2.2 times higher than untreated plot, respectively. These results indicate weed suppression is related with soil surface hardness. The weed suppression with new type of weed controllable materials in upland was showed at the table 3. The plots of WMD-01 (more than $400 \mathrm{~g}$ ) and WMD-02 (more than $400 \mathrm{ml}$ ) showed over $80 \%$ weed suppression value compared to untreated plot. In case of mixture dealt with WMD-01 200g and WMD-02 500m, they showed $96.3 \%$ of weed suppression value compared to $62.9 \%$ and $82.4 \%$ of weed suppression value of each material treatment, and synergic effect was shown. There was no significant difference with the growth of corps, and better weed suppression effect than napropamide plot when new type of weed controllable materials were used for produce a safe crop. 
Table 1. The list of materials and methods in this study

\begin{tabular}{|c|c|c|}
\hline Materials & Dosage $\mathrm{m}^{-2}$ & Treatment methods \\
\hline WMD-01 & $200,400,500 \mathrm{~g}$ & WMD-01 treatment fb. DW $1 \mathrm{~L} \mathrm{~m}^{-2}$ \\
\hline WMD-02 & $400,600,800,1,000 \mathrm{ml}$ & Treatment with sprayer \\
\hline $\begin{array}{l}\text { WMD-01 + } \\
\text { WMD-02 }\end{array}$ & $200 \mathrm{~g}+500 \mathrm{ml}$ & WMD-01 treatment fb. WMD-02 \\
\hline Napropamide & $150 \mathrm{mg}$ ai & Treatment with sprayer \\
\hline Vinyl & - & Mulching \\
\hline Untreated plot & - & - \\
\hline
\end{tabular}

Table 2 . The change of soil surface hardness by environmental-friendly materials treatment

\begin{tabular}{lcc}
\hline \multicolumn{1}{c}{ Treatment } & $\begin{array}{c}\text { Hardness density } \\
\text { of soil surface }(\mathrm{mm})\end{array}$ & \% of untreated plot \\
\hline WMD-01 200 g & 12.3 & 132 \\
WMD-02 1L & 20.7 & 223 \\
Untreated plot & 9.3 & 100 \\
\hline
\end{tabular}

Table 3. The inhibition rate of weeds emergence by environmental-friendly materials treatment

\begin{tabular}{ccccc}
\hline Treatment & Dosage $\mathrm{m}^{-2}$ & Weed seedling No. & Dry weight $(\mathrm{g})$ & Suppression (\%) \\
\hline \multirow{3}{*}{ WMD-01 } & $200 \mathrm{~g}$ & 84 & 96.2 & 62.9 \\
& $400 \mathrm{~g}$ & 30 & 21.1 & 91.9 \\
& $500 \mathrm{~g}$ & 44 & 23.8 & 90.8 \\
\hline & $400 \mathrm{ml}$ & 53 & 51.6 & 80.1 \\
WMD-02 & $600 \mathrm{ml}$ & 41 & 45.6 & 82.4 \\
& $800 \mathrm{ml}$ & 8 & 0.94 & 99.6 \\
& $1,000 \mathrm{ml}$ & 20 & 16.4 & 93.7 \\
\hline WMD-01 + & $200 \mathrm{~g}+500 \mathrm{ml}$ & 11 & 9.55 & 96.3 \\
\hline WMD-02 & $150 \mathrm{mg} \mathrm{ai}$ & 125 & 46.5 & 82.1 \\
\hline Vinyl mulching & - & 0 & 0 & 100.0 \\
\hline Untreated plot & - & 422 & 259 & 0 \\
\hline
\end{tabular}

